\title{
Maternal nicotine exposure altered expression of laminin $\alpha 5$ in lung tissue newborn mice
}

\author{
Mahdi Shariati Kohbanani ${ }^{1,2}$, Mohammad Reza Nikravesh ${ }^{1 *}$, Mehdi Jalali ${ }^{1}$, Alireza Fazel ${ }^{1}$ and \\ Mojtaba Sankian ${ }^{3}$
}

${ }^{1}$ Department of Anatomy and Cell Biology, School of Medicine, Mashhad University of Medical Sciences, Mashhad, Iran. ${ }^{2}$ Department of Anatomy, School of Medicine, Rafsanjan University of Medical Sciences, Rafsanjan, Iran.

${ }^{3}$ Bu-ali Research Institute, Immunology Research Center, Mashhad, Iran.

Accepted 4 September, 2012

\begin{abstract}
Maternal smoking has been clearly demonstrated to be associated with increased health problems in infants and children. Nicotine is a chemical substance with high level of toxicity. It crosses through the placenta and accumulates in the developing organs of fetus. Previous investigation indicated that maternal nicotine exposures induce decreased fibronectin expression in lung parenchyma. In this study, the effect of maternal nicotine exposure on laminin expression of the newborn mice lungs has been evaluated. 24 female pregnant Balb/C mice were divided randomly into four groups as follows: Experimental Group 1 (Exp D1); received $3 \mathrm{mg} / \mathrm{kg}$ nicotine intra peritoneal injection (IP) from gestational day 7 (GD7) to the last day of pregnancy, Experimental Group 2 (Exp D14); received $3 \mathrm{mg} / \mathrm{kg}$ nicotine from $\mathrm{GD}_{7}$ to post natal day 14, Groups 3 and 4; as sham control groups (Sha-Con) received the same volume $(3 \mathrm{mg} / \mathrm{kg})$ of normal saline parallel to experimental groups. At the end of exposure times, all the newborns were anesthetized, their lungs were removed and prepared for immunohistochemical method and real-time polymerase chain reaction. Our finding indicated that laminin alpha 5(Lama5) mRNA expression in the lung of newborn in the nicotine treated Exp D1 decreased by 0.63 fold but increased in Exp D14 by 1.57 fold comparing to Sh-Con groups. Lama5 immunoreactivity was not similar in different parts of the lungs including alveoli and bronchiole, having a significant increase in the experimental groups in contrast to the Sh-Con groups. These data also indicate that maternal nicotine exposure may induce abnormal laminin expression which may cause defects in lung function during life time.
\end{abstract}

Key words: Laminin, lung, nicotine, mouse.

\section{INTRODUCTION}

Maternal smoking has been associated with pregnancy complications, including intra uterine retardation (IUGR), fetal and neonatal death, spontaneous abortion, and premature delivery (Hafstrom et al., 2005; Wickstrom, 2007). Nicotine is the causative agent for these effects, because it is a major pharmacological constituent of tobacco that easily crosses the placenta and is

* Corresponding author. E-mail: doctornikravesh@yahoo.com. Tel: +98 5118002490 . Fax: +98 5118002484 concentrated in the fetus to a higher level than the mother (Chen et al., 2005). The lung has important role as a gas exchanger in survival of the breathing organism. The lungs development occurs in uterus and is prepared to function at birth time but similar to other mammals, final stages of its development do not complete until birth. Disturbance in developmental stages of lung may affect its maturation and resistance to diseases in future life (Sekhon et al., 2004; Wasowicz et al., 1998; Wasowicz et al., 1996). Investigation in animal models showed that maternal nicotine exposures cause a variety of effects on neonatal lungs including; significant suppression of 
alveolarization (Maritz, 1988) and decreased elastin staining of lung parenchyma (Pierce and Nguyen, 2002). Extracellular matrix (ECM) composition are essential for morphogenesis and differentiation of virtually all tissues (Gullberg and Ekblom, 1995). Basement membranes are distinctive extracellular matrices having essential roles in tissue organization and development. Components common to all basement membranes include laminin, type IV collagen, entactin/nidogen, and sulfated proteoglycans (Kruegel and Miosge, 2010). Among the matrix molecules found, laminins are glycoproteins that modulate adhesion and signaling through integrin binding; additionally, they adhere to other ECM molecules (Aumailley and Smyth, 1998). The laminins have such important roles as; cell adhesion, migration, growth, differentiation, angiogenesis and tumor invasions (Suzuki et al., 2005). Each laminin molecule is composed of three non-identical subunit, called the $\alpha, \beta$, and $\gamma$ chains (Bolcato-Bellemin et al., 2003). At least 15 isoform types of laminin have been identified which substantially were synthesized and expressed during fetal and adult periods (Lefebvre et al., 1999; Miner et al., 1997; Nguyen et al., 2002). Several study indicated that Alpha 5 chain of laminin is essential for the lung development, both in embryonic and adult lung (Nguyen et al., 2005; Nguyen et al., 2002), natural development of smooth muscle cell types, basal membrane of blood vessels (Vainionpaa et al., 2006) and digestive tract (Bolcato-Bellemin et al., 2003). Lama 5 is also essential for propagation and polarization of epithelial cells (Fukumoto et al., 2006). Deletion of the gene encoding alpha5 chain of laminin during fetal development in mouse lead to death (Miner et al., 1998) and imposed abnormality in kidney and digestive tract (Lefebvre et al., 1999). In the lungs it would bring about a delay in its evolution along with abnormality in the growth of the surface alveolar cells and disorganization in growth and development of vessels and alveoli (Rahuel et al., 2008; Rebustini et al., 2007). Because Laminins are important BM component essential for morphogenesis of all tissues, in this study we evaluated the effect of nicotine on the expression of lama 5 in lung tissue development of the offspring during gestational time and lactation period.

\section{MATERIALS AND METHODS}

\section{Nicotine administration and tissue preparation}

24 female Balbc/c mice were randomly divided into 2 experimental and 2 control groups $(n=6)$. Sperm positivity in vaginal plaque was designated as day zero of pregnancy. The animals were maintained at the animal house under controlled conditions (12 $\mathrm{h}$ light and dark cycle, $21^{\circ} \mathrm{C}$ and $50 \%$ relative humidity) with laboratory chow and water provided ad libitum. The experimental Group1 (Exp D1) was received $3 \mathrm{mg} / \mathrm{kg}$ of nicotine (N 3876, sigma .com) daily intra peritoneally (IP) from day 7 of gestation to the last day of pregnancy and experimental Group 2 (Exp D14) was received nicotine from day 7 of gestation to two weeks postnatal ( lactation period) (Jalali et al., 2010). The sham control groups (Sh-Con) were received nicotine solvent (Normal saline) at the same period. Finally, the animals were rapidly sacrificed by cervical dislocation and their lungs were removed in postnatal days one (PD1) and fourteen (PD14), then fixed for $24 \mathrm{~h}$ at room temperature in formalin $10 \%$ to use for immunohistochemistry (IHC) study. Finally the tissues were dehydrated in increasing graded ethanol, cleared in xylene and embedded in paraffin.

\section{Immunohistochemistry method}

The $5 \mu \mathrm{m}$ thickness sections were deparaffinized, rehydrated and then washed in PBS $(\mathrm{pH} 7.4)$ for 10 min, Antigen retrieval were carried out with Heat-induction by Tries/EDTA buffer, $\mathrm{pH} 9.0$ for 20 min. The slides were washed in PBS plus $0.025 \%$ Triton X100 for 5 min, and blocked in 10\% normal serum (goat, Sigma, USA) with $1 \%$ bovine serum albumin (BSA) (Sigma, USA) in phosphate-buffered saline (PBS) for $2 \mathrm{~h}$ at room temperature. All the sections were incubated with monoclonal anti laminin antibody (Abcam, 75344, USA) diluted 1: 150 in PBS with BSA $0.1 \%$ for overnight at $4^{\circ} \mathrm{C}$ and then washed three times with PBS. For blocking endogenous peroxides activity the slides were incubated in $0.03 \% \mathrm{H}_{2} \mathrm{O}_{2}$ (Merk, Ggermany) dissolved in methanol (Bidestsn, Iran) for 30 min. Next, tissues were incubated for $2 \mathrm{~h}$ with secondary antibody (Abcam, 97051, USA) diluted $1: 800$ in PBS with BSA $0.1 \%$ for $2 \mathrm{~h}$. After incubation, the sections were washed extensively with PBS for 3 min and treated with DAB (Sigma, USA) solution (0.03 grDAB in $100 \mathrm{ml}$ PBS and $200 \mu \mathrm{l} \mathrm{H}_{2} \mathrm{O}_{2} / 100 \mathrm{ml}$ PBS) for $15 \mathrm{~min}$ at room temperature in dark. After being washed in running water, all the sections were counterstained with hematoxylin for $1 \mathrm{~min}$. Finally, the sections were dehydrated in increasing graded ethanol, cleared in xylene and mounted in glass slide. Laminin reaction in alveoli and lung parenchyma were graded blind by three separate observers (Table 1 ), then percentile median intensity reactivity was calculated and presented in the form of $50 \%(25 \%, 75 \%)$ (Kranenburg et al., 2006).

\section{Real time study}

\section{RNA extraction}

Total RNA was isolated by RNA plus (Cinnagen, Iran) according to the manufacturer's instructions briefly, 50 to $70 \mathrm{mg}$ of lung tissue was homogenized in RNA plus using homogenizer (polytron PT $1200 E$, Switzerland). The homogenate was centrifuged at $12000 \times$ $g$ for $10 \mathrm{~min}$ at $4^{\circ} \mathrm{C}$ to remove insoluble debris and the supernatant was transferred to a fresh micro centrifuge tube (Eppendorf, Germany). Samples were allowed to sit at room temperature for 5 $\mathrm{min}$, and $0.2 \mathrm{ml}$ of chloroform was added per $1 \mathrm{ml}$ of RNA plus ${ }^{\mathrm{TM}}$. The Samples were vortexed (Velp, Italy) for $15 \mathrm{~s}$ and allowed to stand for $5 \mathrm{~min}$ at room temperature. The mixture was centrifuged at $12000 \times g$ for $15 \mathrm{~min}$ at $4^{\circ} \mathrm{C}$. The aqueous phase was transferred to a fresh micro centrifuge tube and an equal amount of isopropanol (Merk, Germany) was added. After 30 min incubation at $-20^{\circ} \mathrm{C}$, the mixture was centrifuged at $12000 \times g$ for $15 \mathrm{~min}$ at $4^{\circ} \mathrm{C}$. The pellet was washed with $75 \%$ ethanol, air-dried, and resuspended in $50 \mu \mathrm{l}$ of diethylpyrocarbonate-treated water. The total RNA was examined by measuring the optical density at $260 / 280 \mathrm{~nm}$.

\section{cDNA synthesis}

First strand cDNA was made using a cDNA synthesis kit (fermentas, Lithuania) according to the manufacturer's instructions. RNA $(3 \mu \mathrm{l})$ was mixed with $1 \mu \mathrm{l}$ of DNase and incubated for $30 \mathrm{~min}$ at $37{ }^{\circ} \mathrm{C}$, (Incubator, Memmert, Germany) and then $1 \mu \mathrm{l}$ of 100 pmole/ $\mu \mathrm{l}$ Oligo $(d T)$ and $8 \mu \mathrm{l}$ of $\mathrm{H}_{2} \mathrm{O}$ were added to each incubated 
Table 1. Grade of immunoreactivity intensity reaction to antibody laminin a5.

\begin{tabular}{ll}
\hline Grade & Reaction \\
\hline$(-)$ & negative \\
$( \pm)$ & very weak \\
$(+)$ & weak \\
$(++)$ & moderate \\
$(+++)$ & strong \\
$(++++)$ & very strong \\
\hline
\end{tabular}

Table 2. Effect of nicotine treatment $(3 \mathrm{mg} / \mathrm{kg})$ from the $7^{\text {th }}$ day of gestation to the $14^{\text {th }}$ day postnatal in the new born mice. The body weight and Lung weight index in new born mice at different days are compared to control groups.

\begin{tabular}{|c|c|c|c|c|}
\hline Variable & $\begin{array}{c}\text { Control } \\
\text { Group PD1 } \\
\end{array}$ & $\begin{array}{c}\text { Experimental } \\
\text { Group PD1 }\end{array}$ & $\begin{array}{c}\text { Control } \\
\text { Group PD14 }\end{array}$ & $\begin{array}{l}\text { Experimental } \\
\text { Group PD14 }\end{array}$ \\
\hline B wt (g) & $1.55 \pm 0.05$ & $1.43 \pm 0.04^{*}$ & $5.84 \pm 0.33$ & $5.28 \pm 0.39^{*}$ \\
\hline L wt (g) & $0.029 \pm 0.001$ & $0.025 \pm 0.004^{*}$ & $0.11 \pm 0.006$ & $0.09 \pm 0.007^{*}$ \\
\hline
\end{tabular}

B wt, body weight; L wt, Lung weight; Values is means $\pm S d,{ }^{*}: P<0.05$

$10 \mathrm{~min}$ at $70^{\circ} \mathrm{C}$ (Thermal cycler, Bioeer, China). After the above step, $2 \mu \mathrm{l}$ of $10 \mathrm{mM}$ dNTP Mix $4 \mu \mathrm{l}$ (fermentas, Lithuania) of $5 \mathrm{x}$ reaction buffer, $1 \mu \mathrm{l}$ of Ribolck (fermentas, Lithuania) and $1 \mu \mathrm{l}$ of reverse transcriptase (fermentas, Lithuania) were added to each sample tube. The tubes were sequentially incubated at $42^{\circ} \mathrm{C}$ for 60 min and. $70^{\circ} \mathrm{C}$ for $5 \mathrm{~min}$ (Thermal cycler, Bioeer, China), and stored at $-20^{\circ} \mathrm{C}$ (Freezer, Sikat, Iran).

\section{Primers and real-time polymerase chain reaction (RT-PCR)}

Real-time PCR was performed using the Max3000p (Stratagene, USA) in a total volume of $20 \mu \mathrm{l}$ per well, containing $10 \mu \mathrm{l}$ SYBR Green® PCR Master Mix ( Pars tous, Iran), $1 \mu$ l of CDNA, $1 \mu$ of primer forward, $1 \mu \mathrm{l}$ of reverse and $7 \mu \mathrm{l}$ of $\mathrm{H} 2 \mathrm{O}$. The designed primers were as allows: Lama a 5- $F$, CGTCCCACAGGAATAGGCT, Lama $a$ 5TACCAACGAAGGGCTGCG, GAPDHF, AACTCCCATTCTTCCACCTTTG, GAPDH-R, CTGTAGCCATATTCATTGTCATACCAG. The CDNA was denatured for $10 \mathrm{~min}$ at $95^{\circ} \mathrm{C}$ and the 35 cycle of $95^{\circ} \mathrm{C}$ for $30 \mathrm{~s}$, $58^{\circ} \mathrm{C}$ for $20 \mathrm{~s}$, and $72^{\circ} \mathrm{C}$ for $20 \mathrm{~s}$. At the end of the runs, melting curves were obtained to make sure there were no primer-dimer artifacts.

Glyceraldehyde-3-phosphate dehydrogenase (GAPDH) mRNA was used as an internal control to measure the relative expression quantity of the target genes. Constructing a standard curve with serial dilutions of known template concentration for each target gene is not feasible. Therefore, dilutions $(1: 1,1: 10,1: 100,1: 1,000$, and $1: 10,000)$ of cDNA from the high quality sample were used to construct a relative standard curve for the target genes. Fold change in laminin gene expression was calculated by $2^{-\Delta(\Delta C T) \text {, where }}$ $\Delta \mathrm{Ct}=\mathrm{Ct}$ (target gene) $-\mathrm{Ct}(\mathrm{GAPDH})$, and $\Delta(\Delta \mathrm{Ct})=\Delta \mathrm{Ct}$ (sample) $\Delta \mathrm{Ct}$ (standard) (Pfaffl, 2001; Wong and Medrano, 2005)

\section{Statistical analysis}

On the basis of staining intensity, sections were graded and MannWhitney non-parametric statistical test was used to compare differences between samples, and student t test used for real time PCR. P-values $<0.05$ were considered statistically significant.

\section{RESULTS AND DISCUSSION}

Our results showed that decrease in lung and body weight of mice offspring born from mothers exposed to nicotine was significant compared to control groups $(P<$ 0.01 ) (Table 2). Analysis of laminin a5 mRNA expression in lung tissue showed that mRNA expression decreased by 0.63 fold in Exp D1 and increased by 1.57 fold in Exp D14 comparing with the Sh Con groups. Statistical analysis indicated that the laminin a5 expression increased significantly from PD1 to PD14 in experimental group $(P<0.05)$ (Figure 1). Immunohistochemical reactivity of lung tissue using rabbit monoclonal antibody against mice was specific for laminin a5 in alveolar septum and bronchioles, showing positive reactivity in immunohistochemical method. The locations of laminin expression in lung tissue were determined according to the intensity of color darkness. Immunohistochemistry data showed that intensity of immunoreactivity of laminin $\alpha 5$ in infant lung alveoli of Sh-Con D1 group reacted moderate with median of $2(2,3)$ while at the same position in infants lung born from mothers affected under nicotine Exp D1 was in average reactivity with median of $3(3,4)$. Statistical analysis showed that this increase was significant $(P=0.01)$. In addition median of reaction intensity of alveoli in Exp D14 was very intensitive $4(3,4)$ compared with Sh Con D14 $(p=0.001)$. Also expression of laminin $\alpha 5$ between Exp D1 and Exp D14 increased significantly $(p=0.01)$ (Figures 2 and 4). Study of immunoreactivity of laminin $\alpha-5$ in bronchioles of Exp 


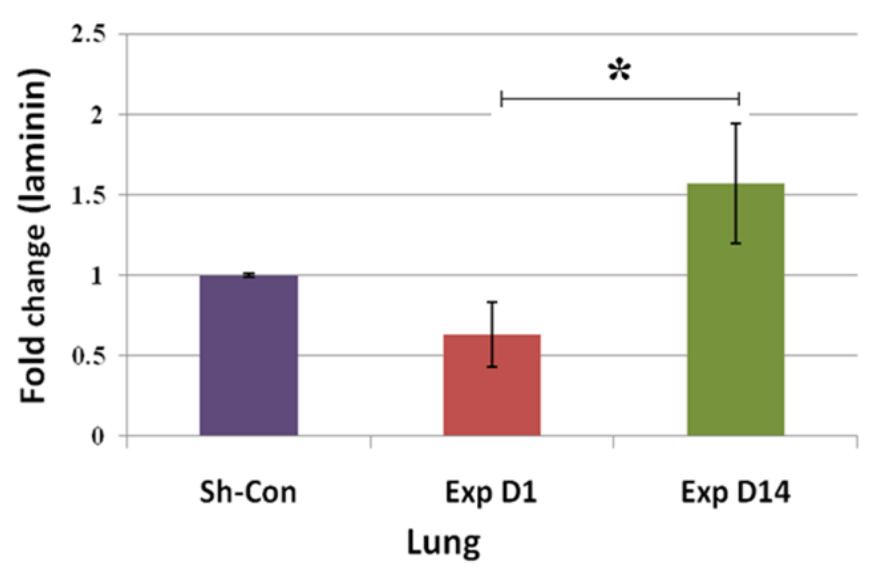

Figure 1. The graph represents the relative transcription level of laminin mRNA expression in lung tissue of the experimental groups under treatment with nicotine $(3 \mathrm{mg} / \mathrm{kg})$ on different days (days 1 and 14 of newborn) using Real-time PCR. Sh-Con ( Sham control), Exp D1 (postnatal day one) and Exp D14 (postnatal day fourteen). Values represent the means \pm SE $(n=$ 6).

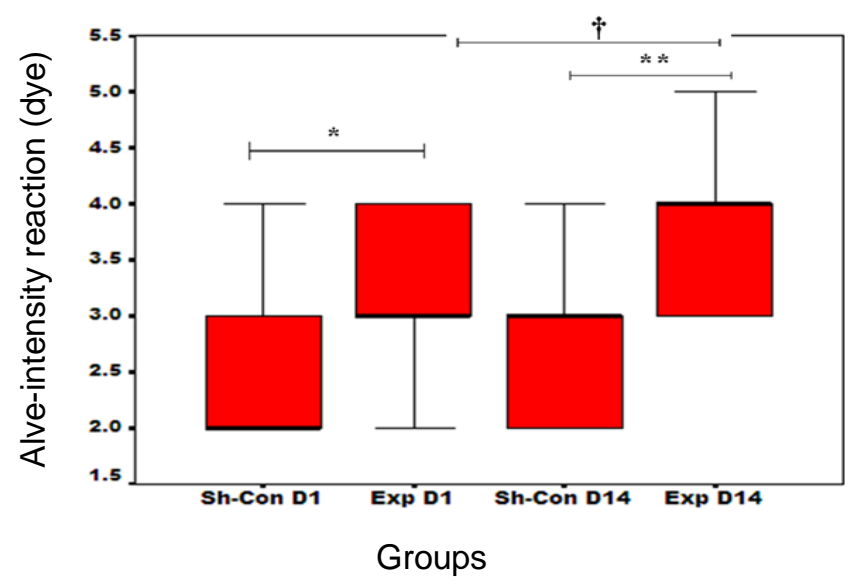

Figure 2. Boxplot shows the effect of maternal nicotine exposure in intensity reaction of laminin $\alpha 5$ in lung alveoli of 1 and 14 days mouse infant. Median is presented in the form of $50 \%(25 \%, 75 \%)$. Sh-Con D1: (Sham control group of day one), Exp D1: (postnatal day one), Sh-Con D14: (Sham control group of day) 14, Exp D14: (postnatal day fourteen). ${ }^{*} \mathrm{p}=0.01$, ${ }^{* *} p=0.001, t p=0.01(n=17)$.

D14 and Exp D1 showed a decrease reactivity in Exp D1 with median $2(2,3)$ comparing with sh-con $3(2,4)$ ( $p$ $=0.002$ ). However, intensity reactivity in bronchioles Exp D14 with median $4(3,4)$ increased significantly comparing with sh-con $3(2,3) \quad(p=0.001)$. Statistical analysis showed that the expression of laminin $\alpha-5$ in bronchioles increased significantly between ExpD1 and $\operatorname{ExpD14}(\mathrm{p}=0.001)$ (Figures 3 and 4$)$.

The results of this study show that nicotine administration during gestation and lactation could change expression of laminin $a 5$ as one of the most

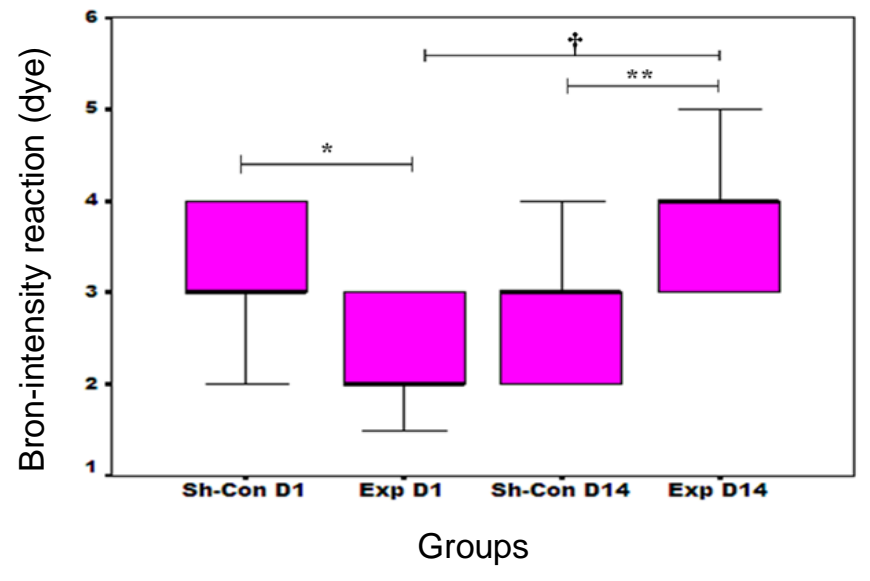

Figure 3. Boxplot shows the effect of maternal nicotine exposure in intensity reaction of laminin $\alpha 5$ in lung bronchiole of 1 and 14 days mouse infants. Median is presented in the form of $50 \%(25 \%, 75 \%)$. Sh-Con D1: (Sham control group of day one), Exp D1: (postnatal day one), Sh-Con D14: (Sham control group of day) 14, Exp D14: (postnatal day fourteen) 14. ${ }^{*} p=0.002,{ }^{* *} p$ $=0.001, \mathrm{tp}=0.0001(\mathrm{n}=17)$.

important proteins of basement membrane. According to IHC analysis, maternal nicotine exposure causes laminin reaction intensity increase in the alveolar septum and derease in bronchiole during gastation period. Therefore, the pattern of laminin expression could be different in various parts of the newborn lungs. Also decrease in expression of laminin would only occur in bronchioles of experimental Group 1 while in experimental Group 2 increased in both alveoli and bronchioles. Although a little difference in lama5 expression was observed in experimental groups using Real time PCR but it was not significant. Changes found for protein levels followed the same time course as those described for mRNA expression. Data obtained from real time PCR and IHC analyses indicated that lama5 expression increased in experimental Groups 2 follow the same developmental pattern. Thus, we concluded that nicotine could have an inhibitory impact on laminin transcription during the gestation period and an stimulatory effect on expression of laminin in laction period.

Luck et al showed that nicotine in maternal smoking results in milk concentrations between 1.5 and 3 times the simultaneous maternal plasma concentration. The nicotine in breast milk is rapidly absorbed through the infant's gut, and accumulates in some tissues (Luck and $\mathrm{Nau}, 1984)$. Accordingly, a reason for increase in lama5 expression in this study might be because of presence of high nicotine concentration in mother breast milk.

Several studies indicated that nicotine acts on nAChRs, which are ligand-gated ion channels controlling influx of calcium and sodium into cells (Akaike et al., 2010). Neuronal nicotinic receptors are present in bronchial epithelium and vascular endothelial cells as well as in the 

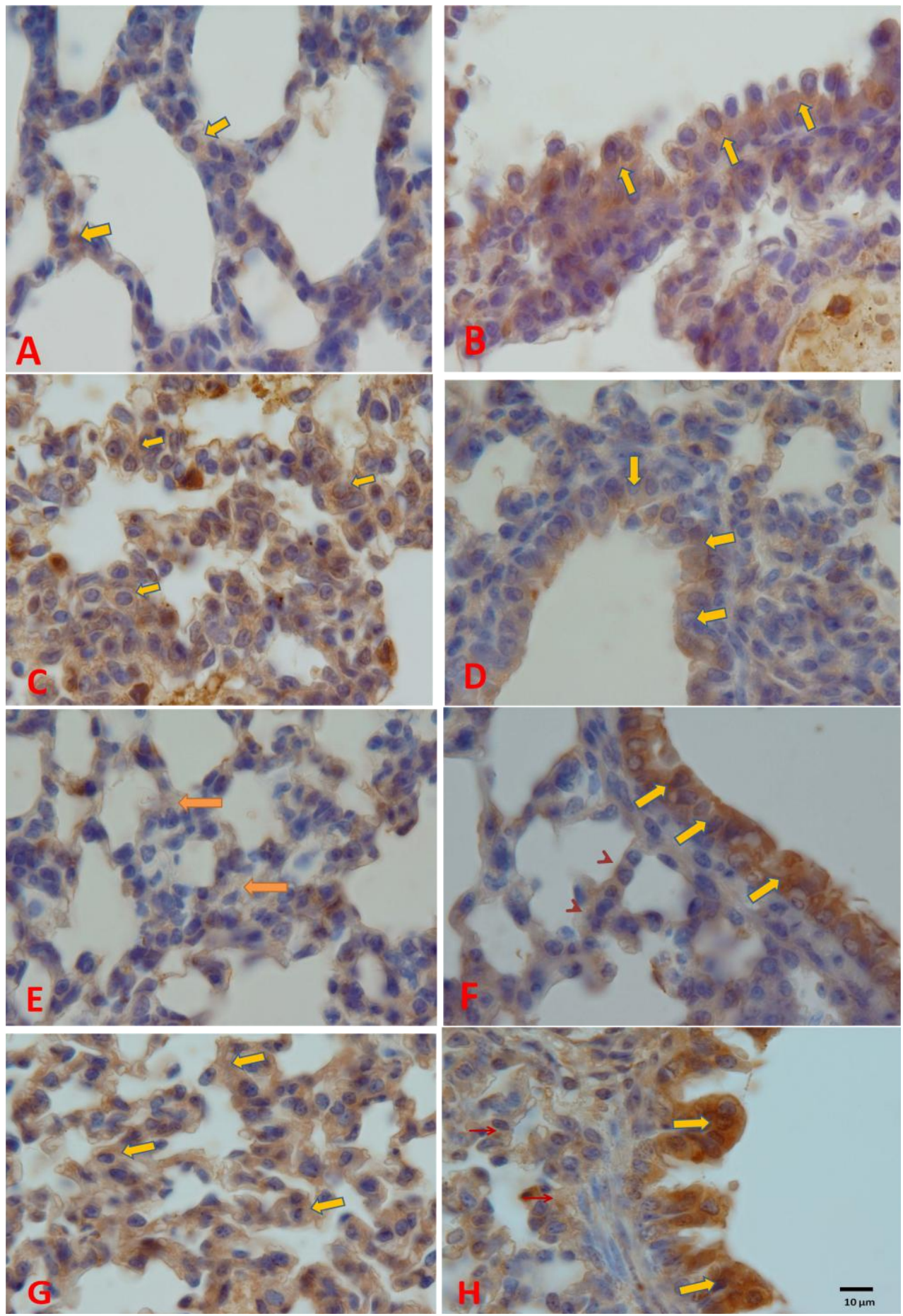

Figure 4. Photomicrographs show epithelium of bronchiole and lung alveoli incubated with laminin $\alpha 5$ antibody (A to H). A, B: alveoli and bronchiole parenchyma in control Group 1; C, D: similar section in experimental groups; E, F: alveoli and bronchiole parenchyma in control Group 2; G, H: similar section in experimental shows increasing reactivity (arrows). Hematoxylin counterstained. (Scale bar $=10 \mu \mathrm{m}$ ).

cholinergic nerves innervating the bronchial smooth muscle (Sekhon et al., 1999; Sekhon et al., 2002). Sekhon et al. (2002) showed that nicotine administration to pregnant rhesus monkeys caused increase in expression of a 7 nicotinic cholinergic receptors within the lungs, which was accompanied by increases in collagen deposition in the airway wall in the lung. The study of Maritz (2009) showed that nicotine increase the 
production of free radicals parallel with a decrease in the lung antioxidant capacity (Maritz, 2009). Furthermore, suppression of glycolysis and an increase in cAMP results in changes in lung growth (Maritz, 2008). Therefore, we propose that the activation or suppression of intracellular signals by nicotine and change in expression of a7 nicotinic cholinergic receptors could lead to increased or decreased laminin gene transcription. In addition, nicotine exposure during gestation and lactation may result in remarkable low pups birth weight. This finding was consistent with the results of other researchers (Ozokutan et al., 2005; Sekhon et al., 2004).

Based on results of other researchers, lung laminin alpha5 can be expressed by endothelial cells, smooth muscles of vessels (Bolcato-Bellemin et al., 2003) and airways epithelial (Nguyen et al., 2005). Decrease in lama5 expression observed in this study may also resulted from malfunctioning of another lung components such as smooth muscles and endothelial vessles.

Several studies showed that laminins affect lung development at multiple stages and in different cellular compartments (Schuger et al., 1990; Willem et al., 2002). Laminin $\alpha 2$ has been shown to be important for bronchial smooth muscle cell differentiation (Relan et al., 1999). Mice lacking laminin $y 2$, or $\alpha 3$ die 1 to 3 days after birth from malnutrition (Meng et al., 2003). A reduction in laminin a5 expression was reported in breast cancers (Martin et al., 1998), Prostate (Calaluce et al., 2001), lung (Akashi et al., 2001; Manda et al., 2000) and colon (Sordat et al., 1998). An increase in expression of laminin beta2 and alpha1 chains have been reported in airway of asthma patients, allergic airway remodeling and chronic obstructive pulmonary disease (COPD). Therefore, change in laminin expression in emberyonic period may cause functional defects especially asthma during either childhood or puberty period. Although above studies highlight the important of laminin in cancer studies but there have not found any record about the effect of nicotine in laminin gene expression.

\section{Conclusions}

In this study, we found that maternal nicotine exposure during pregnancy and postnatal produce variable changes in Laminin a5 gene expression at different stages of lung development. This implies that maternal nicotine exposure might change the future development of lung dysfunction.

\section{ACKNOWLEDGEMENTS}

The provided data in this article are from $\mathrm{PhD}$ student thesis supported by the grant (89566) from vice chancellor for research, Mashad University of Medical Sciences, Iran. In addition, the authors would like to thank Mrs. F. Motejaded for her technical assistance.

\section{REFERENCES}

Akaike A, Takada-Takatori Y, Kume T, Izumi Y (2010). Mechanisms of neuroprotective effects of nicotine and acetylcholinesterase inhibitors: role of alpha4 and alpha7 receptors in neuroprotection. J. Mol. Neurosci. 40:211-216.

Akashi T, Ito E, Eishi Y, Koike M, Nakamura K, Burgeson RE (2001). Reduced expression of laminin alpha 3 and alpha 5 chains in nonsmall cell lung cancers. Jpn. J.Cancer.Res.Gann. 92, 293-301.

Aumailley M, Smyth N (1998). The role of laminins in basement membrane function. J. Anat. 193(Pt 1):1-21.

Bolcato-Bellemin AL, Lefebvre O, Arnold C, Sorokin L, Miner JH, Kedinger M, Simon-Assmann P (2003). Laminin alpha5 chain is required for intestinal smooth muscle development. Dev. Biol. 260:376-390.

Calaluce R, Kunkel MW, Watts GS, Schmelz M, Hao J, Barrera J, Gleason-Guzman M, Isett R, Fitchmun M, Bowden GT (2001). Laminin-5-mediated gene expression in human prostate carcinoma cells. Mol. carcinog. 30:119-129.

Chen CM, Wang LF, Yeh TF. (2005). Effects of maternal nicotine exposure on lung surfactant system in rats. Pediatr. Pulmonol. 39:97-102.

Fukumoto S, Miner JH, Ida H, Fukumoto E, Yuasa K, Miyazaki H, Hoffman MP, Yamada $Y$ (2006). Laminin alpha5 is required for dental epithelium growth and polarity and the development of tooth bud and shape. J. Biol. Chem. 281:5008-5016.

Gullberg D, Ekblom P (1995). Extracellular matrix and its receptors during development. Int. J. Dev. Biol. 39:845-854.

Hafstrom O, Milerad J, Sandberg KL, Sundell HW (2005). Cardiorespiratory effects of nicotine exposure during development. Respir. Physiol. Neurobiol. 149:325-341.

Jalali M, Nikravesh MR, Moeen AA, Mohammadi S, Karimfar $M H$ (2010). Effects of Maternal Nicotine Exposure on Expression of Collagen Type IV and its Roles on Pulmonary Bronchogenesis and Alveolarization in Newborn Mice. Iran J. Allergy Asthma. Immunol. 9:169-173.

Kranenburg, AR, Willems-Widyastuti A, Moori WJ, Sterk PJ, Alagappan VK, de Boer, W.I., and Sharma, H.S. (2006). Enhanced bronchial expression of extracellular matrix proteins in chronic obstructive pulmonary disease. Am. J. Clin. Pathol. 126:725-735.

Kruegel J, Miosge N (2010). Basement membrane components are key players in specialized extracellular matrices. Cell Mol. Life Sci. 67:2879-2895.

Lefebvre O, Sorokin L, Kedinger M, Simon-Assmann P (1999). Developmental expression and cellular origin of the laminin alpha2, alpha4, and alpha5 chains in the intestine. Dev. Biol. 210:135-150.

Luck W, Nau H (1984). Nicotine and cotinine concentrations in serum and milk of nursing smokers. Br. J. Clin. Pharmacol. 18:9-15.

Manda R, Kohno T, Niki T, Yamada T, Takenoshita S, Kuwano $H$, Yokota J (2000). Differential expression of the LAMB3 and LAMC2 genes between small cell and non-small cell lung carcinomas. Biochem. Biophys. Res. Commun. 275:440-445.

Maritz GS (1988). Effect of maternal nicotine exposure on growth in vivo of lung tissue of neonatal rats. Biol. Neonate 53:163-170.

Maritz GS (2008). Nicotine and lung development. Birth Defects Res. C Embryo Today 84:45-53.

Maritz GS (2009). Are nicotine replacement therapy, varenicline or bupropion options for pregnant mothers to quit smoking? Effects on the respiratory system of the offspring. Ther. Adv. Respir. Dis. 3:193-210.

Martin KJ, Kwan CP, Nagasaki, K, Zhang X, O'Hare MJ, Kaelin CM, Burgeson RE, Pardee AB, Sager R (1998). Down-regulation of laminin-5 in breast carcinoma cells. Mol. Med. (Cambridge, Mass) 4:602-613.

Meng X, Klement JF, Leperi DA, Birk DE, Sasaki T, Timpl R, Uitto J, Pulkkinen $L$ (2003). Targeted inactivation of murine laminin gamma2-chain gene recapitulates human junctional epidermolysis bullosa. J. invest. Dermatol. 121:720-731. 
Miner JH, Cunningham J, Sanes JR (1998). Roles for laminin in embryogenesis: exencephaly, syndactyly, and placentopathy in mice lacking the laminin alpha5 chain. J. Cell Biol. 143:1713-1723.

Miner JH, Patton BL, Lentz SI, Gilbert DJ, Snider WD, Jenkins NA, Copeland NG, Sanes JR (1997). The laminin alpha chains: expression, developmental transitions, and chromosomal locations of alpha1-5, identification of heterotrimeric laminins 8-11, and cloning of a novel alpha3 isoform. J. Cell Biol. 137:685-701.

Nguyen NM, Kelley DG, Schlueter JA, Meyer MJ, Senior RM, Miner JH (2005). Epithelial laminin alpha5 is necessary for distal epithelial cell maturation, VEGF production, and alveolization in the developing murine lung. Dev. Biol. 282:111-125.

Nguyen NM, Miner JH, Pierce RA, Senior RM. (2002). Laminin alpha 5 is required for lobar septation and visceral pleural basement membrane formation in the developing mouse lung. Dev. Biol. 246:231-244.

Ozokutan BH, Ozkan KU, Sari I, Inanc F, Guldur ME, Kilinc M (2005). Effects of maternal nicotine exposure during lactation on breast-fed rat pups. Biol. Neonate 88:113-117.

Pfaffl MW (2001). A new mathematical model for relative quantification in real-time RT-PCR. Nucleic Acids Res. pp. 29-45.

Pierce RA, Nguyen NM (2002). Prenatal nicotine exposure and abnormal lung function. Am. J. Respir. Cell Mol. Biol. 26:10-13.

Rahuel C, Filipe A, Ritie L, El Nemer W, Patey-Mariaud N, Eladari D, Cartron JP, Simon-Assmann P, Le Van Kim C, Colin Y (2008). Genetic inactivation of the laminin alpha5 chain receptor Lu/BCAM leads to kidney and intestinal abnormalities in the mouse. Am. J. Physiol. Renal. Physiol. 294:F393-406.

Rebustini IT, Patel VN, Stewart, JS, Layvey A, Georges-Labouesse E, Miner JH, Hoffman MP (2007). Laminin alpha5 is necessary for submandibular gland epithelial morphogenesis and influences FGFR expression through beta1 integrin signaling. Dev. Biol. 308:15-29.

Relan NK, Yang Y, Beqaj S, Miner JH, Schuger L (1999). Cell elongation induces laminin alpha2 chain expression in mouse embryonic mesenchymal cells: role in visceral myogenesis. J. Cell Biol. 147:1341-1350.

Schuger L, O'Shea S, Rheinheimer J, Varani J (1990). Laminin in lung development: effects of anti-laminin antibody in murine lung morphogenesis. Dev. Biol. 137:26-32.
Sekhon HS, Jia Y, Raa R, Kuryatov A, Pankow JF, Whitsett JA, Lindstrom J, Spindel ER (1999). Prenatal nicotine increases pulmonary alpha7 nicotinic receptor expression and alters fetal lung development in monkeys. J. Clin. Invest. 103:637-647.

Sekhon HS, Keller JA, Proskocil BJ, Martin EL, Spindel ER (2002). Maternal nicotine exposure upregulates collagen gene expression in fetal monkey lung. Association with alpha7 nicotinic acetylcholine receptors. Am. J. Respir. Cell Mol. Biol. 26:31-41.

Sekhon HS, Proskocil BJ, Clark JA, Spindel ER (2004). Prenatal nicotine exposure increases connective tissue expression in foetal monkey pulmonary vessels. Eur. Respir. J. 23:906-915.

Sordat I, Bosman FT, Dorta G, Rousselle P, Aberdam D, Blum AL, Sordat B (1998). Differential expression of laminin-5 subunits and integrin receptors in human colorectal neoplasia. J. Pathol. 185:4452.

Suzuki N, Yokoyama F, Nomizu M (2005). Functional sites in the laminin alpha chains. Connect Tissue. Res. 46:142-152.

Vainionpaa N, Kikkawa Y, Lounatmaa K, Miner JH, Rousselle P, Virtanen I (2006). Laminin-10 and Lutheran blood group glycoproteins in adhesion of human endothelial cells. Am. J. Physiol. Cell physiol. 290:C764-775.

Wasowicz M, Biczysko W, Marszalek A, Yokoyama S, Nakayama I (1998). Ultrastructural studies on selected elements of the extracellular matrix in the developing rat lung alveolus. Folia. Histochem. Cytobiol. 36:3-13.

Wasowicz M, Yokoyama S, Kashima K, Nakayama I (1996). The connective tissue compartment in the terminal region of the developing rat lung. An ultrastructural study. Acta Anat (Basel) 156:268-282.

Wickstrom R (2007). Effects of nicotine during pregnancy: human and experimental evidence. Curr. Neuropharmacol. 5:213-222.

Willem M, Miosge N, Halfter W, Smyth N, Jannetti I, Burghart, E, Timpl $R$, Mayer $U$ (2002). Specific ablation of the nidogen-binding site in the laminin gamma1 chain interferes with kidney and lung development. Development 129:2711-2722.

Wong ML, Medrano JF (2005). Real-time PCR for mRNA quantitation. Biotechniques 39:75-85. 